\title{
THE APPLICATION OF GEOGRAPHIC INFORMATION SYSTEMS IN DESTINATION MARKETING
}

\author{
Milica Popović ${ }^{1}$, University of Kragujevac, Faculty of Hotel \\ Management and Tourism in Vrnjačka Banja (Serbia) \\ Snežana Milićević ${ }^{2}$ University of Kragujevac, Faculty of Hotel \\ Management and Tourism in Vrnjačka Banja (Serbia)
}

\begin{abstract}
Contemporary business trends influence tourism destinations to use advantages that modern information technology provides. Geographic information systems (GIS) could be used for those purposes, especially in area of marketing management. In this regard, the subject of this paper is to determine if GIS application in destination marketing has positive impact for tourism offer and demand. The paper is based on secondary data, gathered from academic publications from different scientific fields: tourism and hospitality, marketing and ICT. Research results confirmed the primary hypothesis, which indicated that GIS application could be beneficial for both tourism offer and demand. The significance of the research results is reflected as a contribution to theoretical framework of GIS in the tourism, as well as in making a foundation for implementation of those systems in practical marketing activities on the level of the tourism destination.

Key words: geographic information systems (GIS), tourism destination, destination marketing, integrated marketing activities, promotion in tourism
\end{abstract}

\section{INTRODUCTION}

Development of information technology has influenced directly an occurrence of a large quantity of information in different areas of business activities, available both for the offer and the demand, and the processing and storage has become a significant problem. This rapidly evolving wave of technological advancements has major implications for service management and marketing. Nowadays, tourism is a frontline service industry that integrates new knowledge on technological advancements in strategic, marketing and planning processes (Phillips \& Moutinho, 2014; Buhalis, et al., 2019). This paper offers a critical review of application of geographic information systems in these processes, focusing on its advantages for tourism offer and demand.

GIS are unique because of their emphasis on providing users with a representation of objects in a cartographically accurate spatial system and on supporting analysis and decision-making (Mennecke \& Brian,

1 milicapopovic.hit@gmail.com

2 snezana.milicevic@kg.ac.rs

Vol. 23, бpoj 2/2021, cmp. 33-45 
2000). They are designed to capture information about the planet; to make such information easy to visualize, analyse, and share; and to support a wide range of modelling and theory-building (Longley, et al., 2015).The GIS have been used successfully to solve the complexities of preconstruction planning and support the wide range of spatial analysis used in the logistics perspective of the construction activities (Karan, et al., 2016).

Regarding to the previously mentioned, this research paper is based on three hypotheses:

Hypothesis 1: GIS implementation can provide a differential advantage in the destination marketing.

Hypothesis 2: GIS implementation can improve marketing activities and decision-making process implemented by tourism destination management.

Hypothesis 3: There are multiple advantages for tourists who base their activities in a destination on the usage of GIS.

Tourism activities are highly dependent on spatial information. Selection of tourism destinations and vacation planning have been researched in the area of GIS-science in tourism (Bahramian, et al., 2018). It is necessary to analyse the usage of GIS by both tourism demand and tourism offer since spatial information is significant for a number of marketing decisions with respect to management of pricing, promotions, targeted advertising (Miller, et al., 2007; Jank \& Kannan 2005; Ozimec, et al., 2010).

\section{METHODS}

In accordance with the subject and the defined goal of the research, the paper is based on secondary data, gathered from academic publications from different scientific fields: tourism and hospitality, marketing and ICT.

Based on the data collected, the results of the survey were compared in detail in three steps:

1. GIS - conceptual determinants,

2. GIS application in marketing of tourism destinations,

3. GIS application benefits for tourism demand.

\section{GIS APPLICATION IN MARKETING OF TOURISM DESTINATIONS}

Nowadays, tourism and hospitality industry marks positive growth rate, considering the number of tourism destinations and the heterogeneity 
of the offer, as well as the level of customization which tourism demand requires. World Tourism Organizationasserts international tourist arrivals worldwide grew 4\% in 2019 to reach 1.5 billion (UNWTO, 2020). Although international arrivals plunged $81 \%$ in July and $79 \%$ in August in response to Covid-19 pandemic, it is expected for this number to grow continually in following years (UNWTO, 2020a).

Some authors assert that geographic segmentationis one of the most significant variable of marketing segmentation and tourism marketing (Oppermann, 1997; Lew \& Duval, 2008). Geographers were among the earliest academics to ponder, theorize and examine the sociospatial manifestations of tourism (Dallen, 2018). During last decades many geographical analyses of tourism progression and development were done (Pearce, 1995; Awang, et al., 2009; Hall \& Page, 2009; Devine \& Ojeda, 2017; Saarinen, et al., 2017). Various GIS-related applications and platforms have become a salient source of tourism data in recent years (Ricker, et al., 2013), increasing the significance of spatial data for the tourism industry.

Tourism sector is a spatial phenomenon that requires spatial data collection and processing (Boers \& Cottrell, 2007). Therefore, it should be interesting to analyse certain platforms from the point of view of visitors: is it important for visitors to have knowledge about the destinations prior to the visit? How do these platforms help in the travel planning? Will these platforms change the behaviour of tourists in the destination? (Albuquerque, et al., 2018).

Increased segmentation of the tourism market and tendency for customization have consequently a problem - efficient satisfaction of needs for those distinctive market segments. Oppermann (1997) asserts that the problem is not reflected in defining a large number of smaller segments, but in the fact that is increasingly harder for companies to target them efficiently with their marketing mix. For this reason, all segments of the tourism industry have to innovate their tourism offer continually, in order to provide distinction and market differentiation in regard to competition (Milićević \& Štetić, 2017). Destination management's task is to define the comparative advantages and to transform them into competitive advantages by applying appropriate development strategies (Popesku \& Pavlović, 2013). Therefore, it is necessary that organizations address this problem, and presenting GIS in the marketing arena is an obvious solution.

GIS in tourism can help build tourism resource inventories, strengthen safeguarding the environment during tourism planning, manage and control tourism development in relation to conflicting demands, monitor tourism activities, provide information about tourism 
destinations on the Internet using map-based information, understand tourism behaviour through time-space analysis, raise awareness on the importance of community involvement and participation during the development or simulate and model spatial outcomes of different topics (Ruda, 2016). According to Giles (2004), GIS may be useful for tourism information management system, tourism decision support systems, visitor impact assessment, tourism facility inventory studies and tourismbased land management. Considering these facts, it could be concluded that GIS and spatial data usage through the internet have two-fold advantages. Firstly, making easier the integration and functionality of a variety of data with other applications, and secondly, facilitating easier and wider distribution of data and functionality to the end users. Besides, Web based GIS support system facilitates the user in decision making in addition to providing information on their desired tour programs (Raghuvanshi et al., 2006).

Bertazzon et al. (1997) presented a study where they identified current use and future prospects of GIS applications in tourism marketing. They analysed possible applications of GIS in tourism marketing, considering the market and the organizations. According to the market, they found that GIS applications are focused on "the spatial task of finding, analysing and mapping market characteristics". On the other hand, considering organizations, those applications are "concerned with the spatial tasks of locating, designing, and planning tourism development" (Bertazzon et al., 1997, p. 40).

The development of tools capable of supporting tourism decision making process and enabling potential visitors to get an overview of the touristic resources' diversity are the main purposes for the implementation of GIS applied to tourism marketing (Lee, et al., 2013; Supak, et al., 2015; Albuquerque, et al., 2018). Šećibović, et al., (2006) quote that application of GIS in tourism implies different processes collecting, manipulation and storage of information related to the location where intervention regarding tourism resources in conducted; research of conditions using digital, interactive cards in the process of identifying the most suitable locations for tourism development; integration of databases during trend analyses and determination of itineraries and the direction of tourism movements. Wei (2012) contributes to this list of GIS functions in tourism, adding that tourism management department can get the information that is good for business operations and improve competitiveness by the use of data mining technology. Tourism planning departments can make further development and expansion of planning and forecasting to tourist attractions based on the information. 
Table 1.: GIS application possibilities and implementation in tourism

\begin{tabular}{|l|l|l|}
\hline $\begin{array}{l}\text { Functional capabilities } \\
\text { of GIS }\end{array}$ & $\begin{array}{l}\text { Areas that could be } \\
\text { investigated using GIS }\end{array}$ & $\begin{array}{l}\text { Examples of GIS } \\
\text { application in tourism }\end{array}$ \\
\hline $\begin{array}{l}\text { Data entry, storage and } \\
\text { manipulation }\end{array}$ & Location & $\begin{array}{l}\text { Tourism resource } \\
\text { inventories }\end{array}$ \\
\hline Map production & Conditions & $\begin{array}{l}\text { Identifying suitable } \\
\text { locations for } \\
\text { development }\end{array}$ \\
\hline $\begin{array}{l}\text { Database integration } \\
\text { and management }\end{array}$ & Trends & $\begin{array}{l}\text { Measuring tourism } \\
\text { impacts }\end{array}$ \\
\hline $\begin{array}{l}\text { Data queries and } \\
\text { searches }\end{array}$ & Routing & $\begin{array}{l}\text { Visitor flows and } \\
\text { management }\end{array}$ \\
\hline $\begin{array}{l}\text { Spatial analyses } \\
\text { Spatial modelling }\end{array}$ & Pattern & $\begin{array}{l}\text { Analysing relationships } \\
\text { associated with resource } \\
\text { use }\end{array}$ \\
\hline Decision support & Management & $\begin{array}{l}\text { Assessing potential } \\
\text { impacts of tourism } \\
\text { development }\end{array}$ \\
\hline & & $\begin{array}{l}\text { Quality decision making } \\
\text { associated with tourism } \\
\text { strategy }\end{array}$ \\
\hline
\end{tabular}

Source: Bahaire, T., \& Elliott-White, M. (1999)

Marketing managers of tourism destinations can use GIS provided information for better understanding of major actors in the marketplace, monitoring changes in a business environment, designing reliable marketing plans and strategies, offering sound solutions to specific marketing problems, and improving marketing control (Churchill, 2001; Tull \& Hawkins, 1993; Zikmund, 2000; Leonidou \& Theodosiou, 2004). Viswanathan (2005) emphasizes the significance of GIS in destination marketing and its role for marketing managers to make a competitive analysis of a certain geographic area, including demographic trends, distance between tourists and the hotel/restaurant, location of competition etc. Necessary information could be collected at different levels - states, regions,towns or streets using GIS, which eliminates the role and expenses of using external organizations (Baker \& Baker, 1993; Weber, 1996).

Considering the example of GIS application, stated by Birkin (1999), it is possible to apply this business principle in the area of tourism. Using GIS, tourism destination management could analyse distribution channels, overlaying locations of tourism agencies/tour operators with sales data in order to determine the most suitable locations for marketing activities. However, this could not guarantee the number of 
tourists who visit the destination, which is influenced by number of human, physical, trip and time factors (Lau \& McKercher, 2006). Hence, this method could not be used to determine those tourism agencies/tour operators who are able to sell the largest number of tourism packages (because GIS uses only spatial information). This is the reason it is necessary to include sales data and consider other possible factors that influence distribution of tourism products.

The most frequently used GIS thematic maps in tourism marketing practice are choroplethmaps (with a mean of 4.53 on a seven-point rating scale, where $1=$ "never used" and $7=$ "often used"), GIS-Based Marketing Decisions/103 followed by proportional symbol maps $(\mathrm{M}=$ 3.70) and diagram maps $(M=3.65)$. Cartograms $(M=1.94)$ are rarely used in practice (Ozimec, Natter \& Reutter, 2010). Using mapped customer data, it is then possible to pursue two important aspects of a marketing campaign. First, a potential tourism marketcould be analysed by representing its customer by drawing concentric rings. Decay curves parameters will be based on these analyses, identifying the percentage of incentive tourists. Second, mapped customer data can be used to locate clusters of tourists at which destination management will aim direct propaganda (Hess, et al., 2004).

\section{GIS APPLICATION BENEFITS FOR TOURISTS}

The factors affecting tourists' choices of tourism destinations include human factors (type of individual, travel party, motivations, etc.), physical factors (destination geomorphology), trip factors (main or secondary destination, first-time or repeat visitor, etc.) and the time factor (length of stay in destination, total trip duration). In this aspect, GIS could be used for documenting spatial, temporal movements of tourists through mapping (Lau \& McKercher, 2006). Lin, et al., (2009) show the possibility of following daily movements of tourists in a destination (picture no. 1).

Map-based information for tourists that may be found on websites or at computer information kiosks is a popular application of GIS (Farsari $\&$ Prastacos, 2004). Creating these unique web-portals demands using of an interface, for which license significant financial funds are needed. The different alternative is to use OpenGis interface, that is available today (Minić, et al., 2014). Chang \& Caneday (2011) assert that the feeling of 'usefulness' may be the fundamental motivation for users to access tourism WebGIS while the sense of 'playfulness' or 'enjoyment' may be the mechanism to engage users for interactions. 
Picture 1.: Three-dimensional representation of the movement of tourists in a tourist destination using GIS users

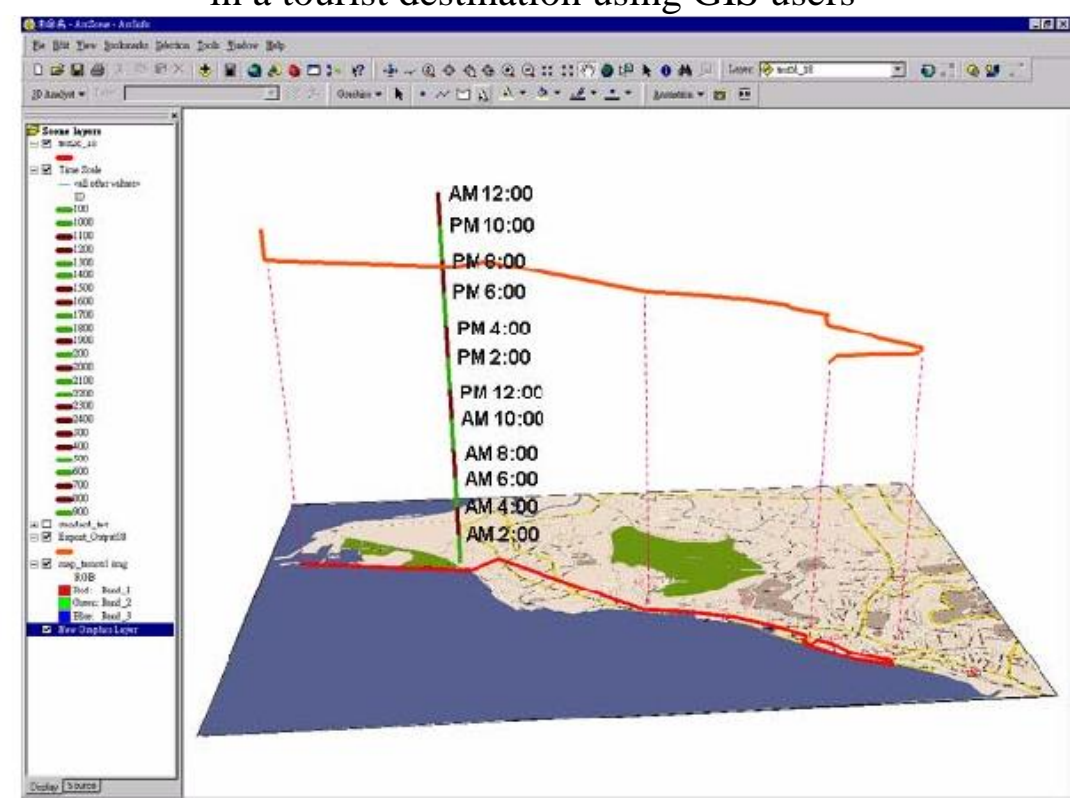

Source: Lin, Chu, Tsai, Chen, \& Chen (2009)

GIS application in tourism destination marketing is reflected as an improvement of tourists' experience, who would be able to find a hotel, restaurant or other service facility in a shorter time period. Besides that, tourists would have available information about destinations offer, which they could use for budget planning before the holiday (Viswanathan, 2005). This strategy is applied by website: http://www.myplacetobe.eu, which is based on geographic database, where a tourist can create the map of tourism destination in accordance to his/her needs using GIS - one person created 118 maps (Goossen, et al., 2009). Considering that the Internet has become the most popular information source, tourism destinations' websites could have a critical role for tourists when choosing a holiday destination (Bastida \& Huan, 2014). Travel-related agencies may develop well-designed, informative and ready-to print maps to enhance visitors' travel experiences. GIS may make it easier for visitors to find their way around their destinations. Using the Internet, it is possible to give prospective visitors a taste of a given destination. Combining photos, sounds and video clips with mapping technology, visitors can plan out their trips ahead of time (Chen, 2007).

Thus, specific key advantages of GIS for tourists are: visualization of tourist destinations and places via maps, digital images and video contents, valuable information about tourist sites, selective information and special activities, such as route planning, accommodation 
information, cultural events, special attractions etc., easily accessible information via Web and interactive maps as a result of personal inquiry of tourists and others (Jovanović, et al., 2012; Cvetković \& Jovanović, 2016).

\section{CONCLUSION}

The use of GIS as a marketing instrument for tourist destinations is an unexplored area in the knowledge system, and accordingly, a more detailed study of the topics and problems that arise in connection with it is required. Tourist destinations should strive for an integrated approach in the implementation of GIS, which is related to the management of the tourist destination, as well as the management of all organizations involved in its offer.

Marketing managers could use information provided by GIS for creating more efficient marketing plans and understanding tourists' movements throughout a destination, as well as to follow trends and competitive actions on the tourism market. This supports the initial hypotheses that GIS implementation can provide a differential advantage in marketing of tourism destinations and improve the decision-making process. Information provided by this research supports the significance of GIS application for tourism demand as well, in order to improve their experience while travelling. This implies better holiday budgeting, faster choosing of hotels, restaurants and other service facilities and unlimited information availability.

The research confirmed the initial hypotheses on which the research paper is based on, including the contribution of using GIS regarding the tourism offer, as well as to tourism demand. Using interactive maps could be beneficial for ensuring a differential advantage on the tourism market and presenting its offer in a specific, visually descriptive way that will appeal to its target market segments.

\section{ACKNOWLEDGEMENTS}

The paper is a part of research within the project No. 179066: "Unapređenje konkurentnosti javnog i privatnog sektora umrežavanjem kompetencija u procesu evropskih integracija Srbije" ("Improving the Competitiveness of the Public and Private Sector through Networking of Competences in Serbia's European Integration Process") financed by the Ministry of Education, Science and Technological Development of the Republic of Serbia. 
The application of geographic information systems in destination marketing

\section{LITERATURE IN A REFERENCE LIST}

1. Albuquerque, H., Costa, C., \& Martins, F. (2018). The use of geographical information systems for tourism marketing purposes in Aveiro region (Portugal). Tourism Management Perspectives, 26, 172-178.

2. Awang, K. W., Hassan, W. M. W. \& Zahari, M. S. M. (2009). Tourism development: a geographical perspective. Asian Social Science, 5(5), 67-76.

3. Bahaire, T., and Elliott-White, M. (1999). The application of geographical information systems (GIS) in sustainable tourism planning: A review. Journal of Sustainable Tourism 7(2), 159-74.

4. Bahramian, Z., Abbaspour, R. A., \& Claramunt, C. (2018). Toward Geospatial Collaborative Tourism Recommender Systems. Book Chapter in GIS Applications in the Tourism and Hospitality Industry (pp. 212-248). IGI Global.

5. Baker, S., Baker, K. (1993). Market Mapping: How to Use Revolutionary New Software to Find, Analyze and Keep Customers. New York: McGraw-Hill.

6. Bastida, U., \& Huan, T. C. (2014). Performance evaluation of tourism websites' information quality of four global destination brands: Beijing, Hong Kong, Shanghai, and Taipei. Journal of Business Research, 67(2), 167-170.

7. Bertazzon, S., Crouch, G., Draper, D., \& Waters, N. (1997). GIS applications in tourism marketing: Current uses, an experimental application and future prospects. Journal of Travel \& Tourism Marketing, 6(3-4), 35-59.

8. Birkin, M., Clarke, G. P., \& Clarke, M. (1999). GIS for business and service planning. Geographical Information Systems, 2, 709722.

9. Boers, B., \& Cottrell, S. (2007). Sustainable tourism infrastructure planning: A GIS-supported approach. Tourism Geographies. International Journal of Tourism Space, Place and Environment, 9(1), 1-21.

10. Buhalis D. \& Licata M. C. (2002). The future eTourism intermediaries. Tourism Management, 23(3), 207-220.

11. Buhalis, D., Harwood, T., Bogicević, V., Viglia, G., Beldona, S., \& Hofacker, C. (2019). Technological disruptions in services: lessons from tourism and hospitality. Journal of Service Management, 30(4), 484-506. 
12. Chang, G., \& Caneday, L. (2011). Web-based GIS in tourism information search: Perceptions, tasks, and trip attributes. Tourism Management, 32(6), 1435-1437.

13. Chen, R. J. (2007). Geographic information systems (GIS) applications in retail tourism and teaching curriculum. Journal of Retailing and Consumer Services, 14(4), 289-295.

14. Churchill, G. A. (2001). Basic Marketing Research. U.S.A.: Harcourt College Publishers.

15. Cvetković, M., \& Jovanović, S. S. (2016). The Application of GIS Technology in Tourism. Quaestus, 8, 332.

16. Dallen, J. T. (2018). Geography: The Substance of Tourism. International Journal of Tourism Space, Place and Environment, 20 (1), 166-169.

17. Devine, J., \& Ojeda, D. (2017). Violence and dispossession in tourism development: A critical geographical approach. Journal of Sustainable Tourism, 25(5), 605-617.

18. Farsari, Y., \& Prastacos, P. (2004). GIS applications in the planning and management of tourism in A. Lew, C.M. Hall \& A. Williams (Eds.) A companion to tourism, Clevedon: Channel View, 596-607.

19. Giles, W. (2004). GIS applications in tourism planning. ISPRS Congress, Comm. II, Istanbul, July 12-23, 2004 (pp. 22-32).

20. Goossen, M., Meeuwsen, H., Franke, J., \& Kuyper, M. (2009). My ideal tourism destination: Personalized destination recommendation system combining individual preferences and GIS data. Information Technology \& Tourism, 11(1), 17-30.

21. Hall, C. M., \& Page, S. J. (2009). Progress in tourism management: From the geography of tourism to geographies of tourism-A review. Tourism Management, 30(1), 3-16.

22. Jank, W., \& Kannan, P. K. (2005). Understanding geographical markets of online firms using spatial models of customer choice. Marketing Science, 24(4), 623-634.

23. Jovanović, V., Njeguš, A., (2007), The Application of GIS and Its Components in Tourism, Yugoslav Journal of Operations Research, 18(2), $261-272$.

24. Karan, E. P., Irizarry, J., \& Haymaker, J. (2016). BIM and GIS integration and interoperability based on semantic web technology. Journal of Computing in Civil Engineering, 30(3), 401-412.

25. Lau, G., \& McKercher, B. (2006). Understanding tourist movement patterns in a destination: A GIS approach. Tourism and Hospitality Research, 7(1), 39-49. 
26. Lee, S. K. (2015). Quality differentiation and conditional spatial price competition among hotels. Tourism Management, 46, 114122.

27. Lee, S.-H., Choi, J.-Y., Yoo, S.-H., \& Oh, Y.-G. (2013). Evaluating spatial centrality for integrated tourism management in rural areas using GIS and network analysis. Tourism Management, $34,14-24$.

28. Leonidou, L. C., \& Theodosiou, M. (2004). The export marketing information system: an integration of the extant knowledge. Journal of World Business, 39(1), 12-36.

29. Lew, A. A., \& Duval, D. T. (2008). Geography and tourism marketing: Topical and disciplinary perspectives. Journal of Travel \& Tourism Marketing, 25(3-4), 229-232.

30. Lin, M. L., Chu, C. M., Tsai, C. H., Chen, C. C., \& Chen, C. Y. (2009). Geovisualization of tourist activity travel patterns using 3D GIS: An empirical study of Tamsui, Taiwan. World Academy of Science, Engineering and Technology, 3(3), 12-25.

31. Longley, P.A., Goodchild M.F., Maguire D.J., \& Rhind D.W. (2015). Geographic Information Science and Systems. UK: John Wiley \& Sons.

32. Mennecke, B.E., Dangermond, J., Santoro, P.J., and Darling, M. (1998) Responding to Customer Needs with Geographic Information Systems. Book Chapter in: S. Bradley and R. Nolan, Sense and Respond: Capturing Value in the Network Era. Boston MA: Harvard Business School Press.

33. Mennecke, Brian E, (2000) Understanding the Role of Geographic Information Technologies in Business: Applications and Research Directions, Journal of Geographic Information and Decision Analysis, 1(1), pp. 44-68.

34. Milićević, S., (2016), Inovativnost u funkciji rasta i razvoja turističke industrije na turističkom tržištu. Megatrend Review, 13(1), 147-158.

35. Milićević, S., Štetić S., (2017). Menadžment u turizmu. Vrnjačka Banja: Fakultet za hotelijerstvo i turizam u Vrnjačkoj Banji, Univerzitet u Kragujevcu.

36. Miller, F. L., Holmes, T. L., \& Mangold, W. G. (2007). Integrating geographic information systems (GIS) into the marketing curriculum. Marketing Education Review, 17(3), 49-63.

37. Minić, N., Njeguš, A., Tulić - Ceballos, J., (2014). The Impact of Web 3.0 Technologies on Tourism Information Systems. Sinteza, (pp. 781-787), Beograd. 
38. Oppermann, M. (1997). Geography's changing role in tourism marketing. Journal of Travel \& Tourism Marketing, 6(3-4), 1-3.

39. Ozimec, A. M., Natter, M., \& Reutterer, T. (2010). Geographical information systems-based marketing decisions: Effects of alternative visualizations on decision quality. Journal of Marketing, 74(6), 94-110.

40. Ozimec, A. M., Natter, M., \& Reutterer, T. (2010). Geographical information systems-based marketing decisions: Effects of alternative visualizations on decision quality. Journal of Marketing, 74(6), 94-110.

41. Pearce, D. G. (1995). Tourism today: a geographical analysis. Journal of Travel Research, 34(2), 202-210.

42. Phillips, P., and Moutinho, L. (2014). Critical review of strategic planning research in hospitality and tourism. Annals of Tourism Research. 48, 96-120.

43. Popesku, J., \& Pavlović, D. (2013). Competitiveness of Serbia as a tourist destination: Analysis of selected key indicators. Marketing, 44(3), 199-210.

44. Raghuvanshi, T.K. Belwal, R. \& Solomon, N. (2006). An approach to develop Tourism Potential in Ethiopia through Geographical Information System. Consortium Journal of Hospitality and Tourism, 11, 35-42.

45. Ricker, B., Johnson P., \& Sieber R. (2012). Tourism and Environmental Change in Barbads: Gathering Citizen Perspectives with Volunteered Geographic Information (VGI). Journal of Sustainable Tourism, 21(2), 212-228.

46. Ruda, A. (2016). Exploring Tourism Possibilities using GIS-based Spatial Association Methods. Geographia Technica,11(2), 87101.

47. Saarinen, J., Rogerson, C. M., \& Hall, C. M. (2017). Geographies of Tourism Development and Planning. International Journal of Tourism Space, Place and Environment, 19, 301-317.

48. Šećibović, R., Maksin - Mićić, M., Komlenović, Đ., Manić, E., (2006). Uvod u Geografiju Turizma sa Osnovama Prostornog Planiranja. Beograd: Centar za izdavačku delatnost Ekonomskog fakulteta.

49. Štetić, S., Šimičević, D., \& Milićević, S. (2017). Information and Communication Technology as a Driving Force of Changes in Tourism. Quaestus, (10), 142-160

50. Tull, D. S. \& Hawkins D. I. (1993). Marketing Research: Measurement and Method. U.S.A.: Macmillan 
51. Viswanathan, N. K. (2005). GIS in marketing. In J. Pick (Ed.), Geographic Information Systems in Business (pp. 236-259). USA: Igi Global.

52. Weber, A. (1996). Enhancement-Plain or Fancy. Target Marketing 19(5): 42/44-45.

53. Wei, W. (2012). Research on the application of geographic information system in tourism management. Procedia Environmental Sciences, 12, 1104-1109.

54. UNWTO (2020). World Tourism Barometer Vol. 18, No. 1. Spain: World Tourism Organization.

55. UNWTO (2020a). World Tourism Barometer Vol. 18, No. 6. Spain: World Tourism Organization.

56. Zikmund, W. G. (2000). Exploring Marketing Research. U.S.A.: Harcourt College Publishers.

Рад је примљен: 24. септембра 2021. Рад је прихваћен за штампу: 30. новембра 2021. 